\title{
Alms and the Man: Fiscal Sectarianism in the Legal Statements of the Shici Imams
}

\author{
EDMUND HAYES (Leiden University)
}

\begin{abstract}
The sociological dimensions of the development of a sectarian orientation in early Imami Shicism have remained sparsely explored since Marshall Hodgson posed the question 'How did the early Shia become sectarian?' in 1955. This article explores Imamic hadith statements on the canonical ritual payment of $z a k \bar{a} t / s ̦ a d a q a$ as a way of tracking the crystallisation of communitarian boundaries. It argues that the Shici Imams, especially Imam Bāqir, fit into a common Muslim discourse regarding the payment of $z a k \bar{a} t$, for example in the case of an unjust Imam. However, the hadiths of the Imam Șadiq show a pivot towards the more clearly differentiated Shici juristic positions of the Occultation period. Imamic statements on zakāt, therefore, must be seen as neither identical to Sunni positions, nor to classical Twelver Shici formulations, but rather as dynamic responses to developing circumstances. In using Imamic hadiths to track early Shici doctrine, this article also suggests directions for the development of a methodology for using hadiths to track historical developments, a venture which has barely begun. In dealing with the Shici Hadith corpus, the author calls for an epistemological scepticism, coupled with a methodological positivism, assuming that while Imamic hadiths may merely act as mouthpieces for later doctrinal positions, it is also very possible that they do originate in the circles of the Imams to whom they are ascribed, and should be analysed as such in order to track chronological developments in the Hadith corpus.
\end{abstract}

Keywords: Minorities, sectarianism, Shia, Shicism, Hadith, Islamic law, zakāt, șadaqa, alms, taxation, charity, group identity

\section{Searching for the origins of Imami Shici sectarianism}

'How did the early Shia become sectarian?' It is a question famously posed in 1955 by Marshall Hodgson in an article of that name, ${ }^{1}$ but one which Hodgson only partially answers. Hodgson approaches the question as an intellectual historian, and primarily from the perspective of the doctrine of the Imamate, using the terminology and source material provided by the heresiographers. Given that his question was about the process of sectformation, however, and therefore an essentially sociological question, it is appropriate also to investigate the institutional framework for the establishment of the Imami Shia as a distinct group. Since Hodgson, the study of early Shi'ism has continued to be overwhelmingly doctrinal in its focus. ${ }^{2}$ In this article, I will make a step towards bridging the gap between early Shici intellectual and sociological history ${ }^{3}$ by interrogating the social effects

1 HOdGSON 1955.

2 Notable recent exceptions to this include HAIDER 2011 and HAIDER 2009; ASATRYAN 2014.

3 I use the term 'sociological history' in conscious distinction from 'social history'. While 'social history' tends to designate the history of normal people in societies, rather than just the history of elites, 
of the legal rulings of the Imams. These legal rulings certainly were part of an intellectual discourse between scholars; however, I will use them to cast light upon the origins of the development of the Imami Shia community structures-in particular the development of distinctive practices for the collection of the alms tax (zakāt).

Within the current issue's discussion of Islamic Law and minorities, it must be stressed that, in fact, the Islamic law pertaining to minorities finds its first origins at a time when the now-minorities were majorities, while the Muslim Arab elites were themselves still a minority amongst the conquered lands. ${ }^{4}$ Nonetheless, Sunni law, at least, may be seen as representing the perspectives of a more or less dominant, hegemonic position associated with the ruling political and intellectual elites of Islamic society. In contrast, the substance of Shi' $i$ positive law based on the statements (hadiths or $a h b \bar{a} r$ ) ascribed to the Imams increasingly developed with a self-consciously minoritarian, sectarian perspective: a self-defining minority, that is. ${ }^{5}$ The distinct sectarian identity that is visible in the classical system of Imami Shic $i$ law, ${ }^{6}$ however, was a work in progress that emerged gradually over several generations. This process is poorly understood, largely because of the difficulty of finding good sources for early Imami Shi'i social and political history. ${ }^{7}$ Indeed, the study of group identity and group definition in early Muslim sects as a whole is hampered by the fact that the heresiographical nature of many of the earliest sources does not provide us with a firm basis for distinguishing between a real group whose members would have recognised each other in the world, and a theoretical construct produced by a scholarly desire to systematise the available information into elegant heresiographical categories. ${ }^{8}$

In what follows, I aim to show that one way of going beyond the heresiographical definition of a group is to 'follow the money'. The Shi' $i$ conception of who should collect, distribute and receive the Islamic canonical alms taxes provides us with a conceptual framework that helps us understand the ideal structural characteristics of the community and the way it maintained boundaries with other communities. In particular, the distinctions about to whom one should pay zakāt must be understood as functioning clearly to mark affiliation and loyalty to a particular group and leader, in a way that the more fluid realm of doctrinal belief cannot. I will focus on two particular questions in the Shici law of zakāt that

'sociological history' is concerned with the theories and structures upon which society is based. In this article, I aim to elucidate not just the narratives of Shici history, but rather the structural dynamics of the Shi' i community, insofar as these structures can be reclaimed.

4 BULliET 1979. Formal hadith collection efforts were well under way during the lives of these Imams, though the great mușannaf and sahịh hadith collections of the $9^{\text {th }}$ and $10^{\text {th }}$ centuries, were compiled after this point had been reached. See BROWN 2009: 18-34.

5 For an overview of the sectarian perspective in early Shi' i sources, see KOHLBERG 1988 and KOHLBERG 1985; DAKAKE 2007.

6 By 'classical' in the context of Imami Shici law, I refer to the foundational texts of the Occultation era, before the Safavids, especially the $11^{\text {th }}-14^{\text {th }}$ centuries, when the foundational doctrines of the sect had stabilised, and the use of both hadith and rational ușūli methodologies had been widely accepted.

7 Many of the most important figures in the Imami community are ignored as insignificant by non-Shici historians and biographers. Even the Imami Imams are the subject of scanty discussion in the major historical chronicles and biographical dictionaries.

8 This includes the desire to sort messy realities to conform with the hadiths of about 72 or 73 sects. See VAN ESS 2003: 216; HAIDER 2007: 368. 
are pertinent to the task of determining the nature and expression of the commitment made to one's community: first, whether one should allow zakāt to be collected by an unjust Imam; and, second, if one distributes it oneself, how communitarian boundaries shape the practice of this ritual giving. ${ }^{9}$

\section{Methodology}

The evidence I analyse below is centred on the statements of the Shi' $i$ Imams Abū Ğacfar Muhammad al-Bāqir (d. 117/735, 114/732-733, or 118/736) and Abū 'Abd Allāh Ğa ćar alȘādiq (d. 148/765) regarding the Islamic canonical tax known as șadaqa or zakāt. Many of their statements regard the precise quantities and timing of the payment of sadaqa/zakāt, and many replicate what one can find in Sunni hadith collections. I focus on those statements that present distinctive information on the relationship between giver, collector and recipient of zakāt. The richest vein of material I have found is in the chapters of zakāt and the chapters on hums in the earliest large Twelver hadith compilations, of Kulaynī and Ibn Bābūyah, both of whom were active in the $4^{\text {th }} / 10^{\text {th }}$ century, and thereby represent some of the earliest extant texts that contain substantial numbers of fiscal hadiths. ${ }^{10}$ I will suggest that there are some indications that reports in the Hadith corpus as it pertains to zakāt do appear to reflect intellectual developments dating from the time of the Imams. At the very

9 Ritual militates against a stable definition, and a practice like zakāt clearly has an instrumental or 'rational' function, as well as being a ritual expression of commitment, fulfilling a soteriological and purificatory function. As Edmund Leach suggests, even though 'no useful distinction may be made between ritual acts and customary acts but that in discussion of ritual we are concerned with aspects of behaviour that are expressive (aesthetic) rather than instrumental (technical). Ritual action, thus conceived serves to express the status of the actor vis-à-vis his environment, both physical and social'. See LEACH 2000: 173. This framework for the way in which sacred and the economic meet (in contrast to Durkheim's more complete separation of the sacred and the profane) provides a framework for our understanding of the ritual nature of the act of giving zakāt. Shi $i$ alms/tax-giving practices communicate a commitment to a particular Imam, and thereby membership in a particular community. In addition to having a mundane "rational function' - the social redistribution of wealth - they also have a soteriological function of guaranteeing the legitimacy of prayer, and enabling the believer to attain paradise. While zakāt may be considered an instrumental financial institution that has the effect of redistributing wealth in the community of the faithful, it is also one element of a larger ritual, material and aesthetic complex that ties the believers to the Imam. The giving of money to the Imam is often portrayed as part of a pilgrimage sequence that sometimes includes the hajj as well as a pilgrimage to the house of the Imam. Reports describing visits to the Imam or his agents often involve payment of money, but they also describe the circulation of gifts in the opposite direction, from the Imams to their followers, including written blessings and ritual objects like funerary shrouds and funerary balm. I have called this system, the 'sacred economy' of the Imamate, as a way of uniting both the ritual-sacral aspect with the instrumental aspect of the redistribution of wealth. See HAYES 2015. This, however, deals with a later period, and it will require further research to understand when the different elements of this sacred economy might first have been established. For one of the numerous examples where bringing money to the Imam is seen as part of the hajj pilgrimage, see IBN BĀBŪYAH, Kamāl al-dīn, 516-17.

10 I surveyed most of the major early Imami hadith compilations and tafsirs from the $8^{\text {th }}$ to the $11^{\text {th }}$ centuries, before confining my study to these two collections, which contained the most important hadiths for this topic. Among the non-Imami sources, I surveyed the following: al-NU'MĀN, Da'ẩ'im al-Islām; Imām alHĀDİ ILÀ 'L-ḤAQQ YAHYYĀ b. al-Ḥusayn, Kitāb al-aḥkām fì 'l-ḥalāl wa l-ḥarām.

jحis • 17 (2017): 280-298 
least we can say that the Imams' statements do not easily conform to the mainstream opinion of later Imami jurists that zakāt should only be paid to the true Imam, and should not be paid to non-Shic is. ${ }^{11}$ As such, I will approach the Imami Imams' statements on șadaqa/ zakāt on their own terms, rather than attempting to align them with later Imami doctrine.

Our understanding of the dynamics of the formation of the Shi'i Hadith corpus has advanced tremendously in the past few decades, but much detailed work remains necessary to understand the processes of formation, transformation, reproduction and preservation that lead to the form and content of the hadith collections as we have them today. ${ }^{12}$ While legal hadiths do not tend to display the same tendency to fit suspiciously into narrative tropes as historical $a h b \bar{a} r,{ }^{13}$ they were clearly formed and developed in response to ongoing debates over legal and political frameworks for correct ritual practice. My work is partly informed by the Schachtian understanding that hadith reports often reflect later disputes rather than the ideas of the people to whom they were ascribed. However, though I work with an epistemological scepticism, at our current stage of analysis of the Shici Hadith corpus ${ }^{14}$ I deem it necessary to introduce a certain methodological positivism. Thus, I work with the assumption that the hadiths ascribed to certain Shici Imams might indeed originate with those Imams, or men in their circle. While this may prove to be an operational fiction, it will provide a methodology to help us begin to understand the internal dynamics of the Shici Hadith corpus. ${ }^{15}$

\section{Shi'i zakāt law}

Hitherto, scholarship on Shi'i zakāt law (and indeed Shici fiqh in general) has been focused on juristic discourses of the Occultation era, especially from the $5^{\text {th }} / 11^{\text {th }}$ century onwards. ${ }^{16}$ Thus, the nature of the individual contributions of the Imams, or, for that matter, of the late-Imamic and early-Occultation era jurists, is very poorly understood. While much work remains to be done to understand the legacy of these men, we can summarise by saying that Bāqir and Șādiq were widely seen as wise, pious, knowledgeable men from a prestigious 'Alid lineage who became the focus of intensive Shici piety and mobilisation, probably

11 KoHLBERG 1985: 101; ZYSOW, 'Zakāt', $E I^{2}$.

12 Key works of scholarship that contribute to our developing framework for understanding early Shici hadiths are the many works of Etan Kohlberg, many of which are collected in KOHLBERG 1991; MODARRESSI 2003; and the work of Robert Gleave, especially GLEAVE 2001; NEWMAN 2000; HAIDER 2011; the works of Hassan Ansari, including ANSARI 2013.

13 Noted especially in NOTH \& CONRAD 1994.

14 Shici hadith is substantially different from Sunni hadith. In contrast to the Prophetic hadiths that are so central to Sunni law, Imami Shici hadiths are most often ascribed to the Imams of the second/eighth and third/ninth century, placing them right in the era of hadith compilation. This, and other distinctive factors, require that a comprehensive framework for understanding and working with shici hadiths should be developed.

15 This methodology is partly informed by Robert Gleave's analysis of Imamic hadiths, for example in GLEAVE 2010.

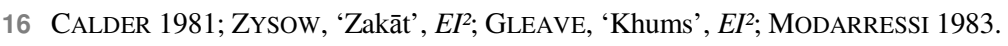


during their lifetimes but certainly in the generations to follow. ${ }^{17}$ Sadaqa/zakāt refers to a kind of taxation or alms ${ }^{18}$ that was required of every Muslim of means as part of her membership in the Muslim community, along with the șalat prayer and other duties. The origins of șadaqa/zakāt, like many institutions rooted in the earliest phases of the Islamic community, are murky, ${ }^{19}$ and by the time of Bāqir and Șādiq, a juristic enterprise was under way to impose order on the ad hoc revenue-generation mechanisms that had emerged during the first century and a half of the Islamic community. A distinction is often made in later juristic literature between șadaqa as referring to voluntary charitable gifts to the needy, and zakāt as referring to the obligatory payments incumbent on every Muslim of means, ${ }^{20}$ but this distinction is usually not visible in the hadiths themselves, where sadaqa is the dominant term for both forms. There is also a distinction between zakāt, which is due every year, based on capital wealth and/or income, and the obligatory zakāt al-fitr, which is distributed at the end of Ramadan. In addition, the early juristic sources exhibit confusion over the categorisation of the agricultural tithe ( ${ }^{\mathrm{C}} u \bar{s} r$ ), which was sometimes considered as zakāt, and sometimes categorised under harāg. ${ }^{21}$ When dealing with the short telegraphic Imamic statements, which are shorn of context and recompiled in hadith works, we often cannot tell exactly which kind of subcategory of zakattșadaqa we are dealing with. In these statements, as in other examples of early juristic writing and hadith, șadaqa and zakāt are usually used synonymously, or at least with a great deal of semantic overlap. Sadaqa is the term most often used in hadith reports, while zakāt tends to be used as the rubric under which these hadith reports were compiled, reflecting the ongoing process of systematisation of terminology. The rubrication of these chapters provides ambivalent testimony, as it often seems to conflate, under the rubric of zakāt or hums, hadiths from very different contexts in order actively to construct a particular view of Imamic practice. Thus, though I draw largely upon the chapters on zakāt or hums, I do not treat them as essentially belonging to those chapters.

Șadaqa and zakāt should be seen within a broader ecosystem of other Islamic canonical revenue categories such as 'ušr, harāğg, hums, ǧizya, and waqf, which are also characterised by a greater or lesser terminological ambiguity, and often overlap with each other. ${ }^{22}$ In the Shici context, it is helpful to compare the developing discourse on zakāt with the hums, both of which came to be understood as scriptural categories of Islamic canonical tax or alms, the payment of which indicates one's commitment to a particular leader or govern-

17 See, for example, Hodgson 1955; Hodgson, 'Dja a far al-Șādiḳ', EI²; KoHLBERG, 'Muhammad b. 'Alī Zayn al-'Ābidīn, Abū D ja 'far, called al-Bākịi', $E I^{2}$.

18 There is no clear distinction made in the early sources between autonomously-distributed, voluntary 'alms' and mandatory, governmentally-collected 'tax', other than what can be inferred through context; both 'tax' and 'alms' will be used in the course of this article, depending on whether the context suggests that it was collected by the Imam/caliph or his appointees, or distributed autonomously by the individual. However, context is often not a clear guide.

19 The best guide to the perplexing variety in the earliest usage of șadaqa/zakāt is BASHEAR 1993.

20 ZYsow, 'Zakāt', $E I^{2}$.

21 SATO, 'Ushr', $E I^{2}$.

22 See, for example, HENNIGAN 2014 on the terminological confusion between waqf, șadaqa, and other categories.

jحis • 17 (2017): 280-298 
mental structure. The major difference between these in the Shici context came to be the fact that while the Imam was not allowed to use the șadaqa/zakāt for himself, due to the fact that he belonged to the ahl al-bayt, ${ }^{23}$ the hums, on the other hand, came to be viewed as the Imam's personal prerogative. ${ }^{24}$

\section{Zakāt and Imamate: The fiscal claims of the Imami Shici Imams}

As is well known, sect-formation in Islam was set in motion by the very first conflicts that followed the death of Muhammad and developed in the generations to come. The Umayyad rulers began to develop an imperial style, a body of bureaucratic and legal practices and rulings, and an ideology of religiously legitimated rule. Meanwhile, a varied set of movements developed oppositional ideologies, tracing their opposition back to the example of 'Alî's conflict with the Umayyads, and holding out hope that one of his descendants or family members would recreate a rule of justice they felt to be lacking. However, the early Shia were not a homogenous movement, but rather a collection of diverse responses to the legacy of 'Ali and the prophet's family. ${ }^{25}$ It is hard to know when and to what extent the Shi $i$ group identities came to be expressed in recognisably communitarian elements such as geographical separation, divergent beliefs, and separate ritual practices. Dakake has argued that, from the lifetime of 'Alī, his followers' support has had a theological content, most especially the idea of walāya as a binding charismatic contract, which formed the foundation for later developments in Shici thought. ${ }^{26}$ It is likely that very soon, pre-existing tribal and local identities came to be woven into new 'Shi' $i$ ' expressions of communal identity and ritual practice. Najam Haider notes that, in relation to second/eighth century Kufa, Shic i life was deeply textured by its embodiment in particular locales, and particular ritual practices, such as ways of praying, which marked the Shici practitioners apart from their neighbours. ${ }^{27}$ Shici community identities, therefore, were not imposed purely from above by Imams and elites. Much of what came to be constituent of 'Shi'i identity' would have emerged from the grass roots, and some of this would have been pseudonymously placed into the mouths of the Imams to add to its authority.

The crystallisation of systematic theories of the Imamate, produced by intellectual elites among both Shia and non-Shia, was significant, however. The Imami Shici theory of Imamate first appears to have crystallised in the second/eighth century, in the circle of Ğa ${ }^{c}$ far al-

23 Who was and was not able to receive zakāt depends on the definition of the phrase ahl al-bayt, who, it was agreed, were not allowed to receive the zakāt/șadaqa. The interpretation of ahl al-bayt developed gradually, and its meaning has come to range from just the prophet's wives, to encompass the entire tribe of Hāšim (for example for Abū Hanīfa and al-Šāfi'ī). See GoldZIHER, VAN ARENDONK \& TRITTON, 'Ahl al-bayt', $E I^{2}$.

24 On the early development of the Imami hums, see MODARRESSI 1993: 12-18. For later developments, see CALDER 1982. Neither of these, however, presents the final word on the early development of hums.

25 For the diversity and fragmentation of the early Shia, see VAN ESS 1991, I: 272-274.

26 DAKAKE 2007.

27 HAIDER 2009. 
Șādiq ${ }^{28}$ in opposition to the developing Umayyad ideology and theology of rule, ${ }^{29}$ and in gradually clearer distinction from other Shici schools of thought. Hodgson has argued that the creation of a stable Imami Imamate, predicated on father-to-son transmission and explicit designation, allowed for generation-to-generation consolidation. ${ }^{30}$ The establishment of the Imams' revenue-collection protocols must be seen as a part of the broader institutional and conceptual foundation of the Imami Imamate.

While the Imami Imams have typically been seen as 'quietist', compared to the more 'activist' Zaydi Shia, the Imami legal hadiths on hums and zakāt problematise this assumption. As we shall see below, Imami legal hadiths suggest that the Imams ordered the Shia to pay zakāt to them or their functionaries, in preference to the functionaries of the Caliph. What was the creation of the Imami Shici financial system meant to achieve? The creation of a state within a state? Preparation for future rebellion? Certainly, some sources indicate that 'Abbasids perceived Imami revenue collection as a threat, prompting the persecution of the Imam's followers. ${ }^{31}$ Part of the problem here is that we have few sources for understanding the actual practice of zakāt collection, whether by the caliphal government or among oppositional groups, though Petra Sijpesteijn has made an important contribution through her work on the Egyptian papyri and their evidence for governmental collection of șadaqa. ${ }^{32}$

\section{The fiscal claims of the Imami Shi'i Imams}

At some point, probably during the mid to late second/eighth century, the Imams began to assert their right to collect Islamic canonical revenues. ${ }^{33}$ A motley system of gifts and contributions to the Imams probably already existed. These were supplemented and explained by an increasingly systematic set of canonical dues, which were established by associating them with existing Quranic categories of canonical alms taxes, the payment of which marked one's commitment to an Imam. ${ }^{34}$ These categories also paralleled Umayyad governmental efforts to legitimise their revenue collection, resulting in an implicit conflict. While we cannot be sure of the exact timeline of historical development of the Imami revenue collection system, one historical circumstance stands out as a terminus ante quem for the existence of substantial Imami Shici institutions of revenue collection. Upon the death of Ṣādiq's son, the seventh Imam, Abū 'l-Ḥasan Mūsā al-Kāẓim, in 183/799, a group of

28 See MADELUNG, 'Hishām b. al-Hakam', $E I^{2}$.

29 CRONE \& HINDS 1986, especially pp. 24-57.

30 HODGSON 1955.

31 See, for example Rašīd's distrust of Mūsā al-Kāẓim, due to the rumour that he 'was receiving donations from all corners of the earth'. KOHLBERG, 'Mūsā al-Kāẓim', $E I^{2}$.

32 See SiJPESTEIJN 2013.

33 I deliberately use this vague wording because it is not clear in what form the Imams first justified their collection of monies from their followers.

34 For a discussion of the different kinds of semi-canonical payments made to the Imams, see HAYES 2015: 86-105.

jحis • 17 (2017): 280-298 
Kāẓim's agents rejected his successor, claiming that Kāẓim had gone into Occultation, and they then refused to hand over to his successor the apparently large amounts of money they had collected in Kāẓim's name. ${ }^{35}$ This provides clear proof that at least by the time of Kāzim there was a substantial amount of money being collected in the name of the Imam. The collection of these large sums from the community would have required some form of doctrinaltheoretical justification - either developed pre-emptively, or, more likely developed ex post facto. The Imamic statements on the Islamic canonical taxes (especially zakāt and hums) were a part of this conceptual backdrop for the development of community funding mechanisms. This is not to say that all of these categories of revenue would have been treated the same once collected. On the contrary, the rules regarding the use of zakāt and hums are distinguished, for example, by the fact that no part of the zakât could be used by the Imam for his own purposes, unlike the hums, due to the fact that the zakāt donations were conceived as carrying away the impurity from the donors, something which the ahl al-bayt could not accept due to their pure lineage. ${ }^{36}$

While many of the statements of Bāqir and Șādiq are difficult to contextualise historically, we may assume that Kāzim's revenue-collection system did not emerge without any precedent. We can find suggestive material in statements like the following, in which Saādiq is depicted as justifying his collection of zakât, or some similar tax, perhaps in the face of a sceptical community:

Ibn Bukayr reported: I heard Abū 'Abd Allāh [Șādiq] (AS) say, '[If] I take a dirham from one of you, and even though I am one of the wealthiest people in Medina, in doing so I wish nothing else than that you should be purified (tuthirū) ${ }^{3}{ }^{37}$

While this does not explicitly mention șadaqa or zakāt, the apologetic tone suggests that the Imam may be defending an innovation he has made in collecting money from his followers, who do not all consider it to be fully warranted. The context suggests the ritual function of purifying the donors that is associated with the payment of sadaqa and zakāt, based on the Quranic usage. ${ }^{38}$ If Șādiq were indeed claiming the zakāt, then this would seem to imply a direct challenge to the caliphal prerogative of collection of the canonical Islamic revenues. ${ }^{39}$ While this statement is not clearly datable, the apologetic tone suggests that it derives from a period in which payment of canonical dues to the Imam was not a self-evident duty, but something that had to be established through statements ascribed to the Imam.

35 BUYUKKARA 2000.

36 ZYSOW, 'Zakāt', $E I^{2}$.

37 KULAYNī, al-Käfï, II: 44 . Note that all translations in this article are my own, unless otherwise stated.

38 Quran 9:103. In the Imami context, the hums is also said to have a purificatory role, though it is not said to contain the dregs of impurity that prevents zakāt from being used by the ahl al-bayt. KULAYNĪ, al-Käfì, I: 546.

39 Modarressi also refers to reports in which the 'Abbasid caliph Manșūr is said to have complained that Șādiq was receiving zakāt, and even haräğ land taxes from his followers. MODARRESSI 1993: 13. 


\section{Payment of canonical taxes to an unjust Imam}

One of the matters of controversy among early jurists was the extent to which imperfect governmental authorities could be entrusted with the weighty duty of collecting and distributing a believer's șadaqa/zakāt. Towards the end of the Umayyad period, the pietyminded juristic movement (which formed the immediate intellectual context for the legal statements of Bāqir and Șādiq) was often hostile, or at least ambivalent, towards Umayyad power, hence Hodgson's reference to the intellectual pioneers of the time as part of a 'pious opposition'. ${ }^{40}$ Though the extent of the participation of the scholars in a 'pious opposition' has been recently challenged by Steven $\mathrm{Judd}^{41}{ }^{41}$ we can still use the phrase to apply to the common cause made against the Umayyads by many pious scholars (albeit not all) amongst the Shia and proto-Sunnis. This ambivalence towards Umayyad power prompted the question of whether it was legitimate to pay zakāt taxes to an unjust ruler, a question perhaps exacerbated by innovations in the conception and practice of these taxes. ${ }^{42}$ The divergent responses to this question crystallised into the positions espoused by classical jurists, some of whom counselled a maximalist acceptance of governmental tax and the legitimacy of those who collected it, others a minimalist approach. Zaydis, for example, tended to stress the Imam as the only legitimate collector and distributor of the alms taxes, while at the other end of the spectrum, Hanbalīs tended to recommend that believers should distribute the alms tax personally, whenever possible. ${ }^{43}$ If the ruler were corrupt, then this would complicate matters, and though the Sunnis were generally more tolerant about a corrupt Imam than the purist Shia, some Sunnis still did not allow payment of the canonical taxes to a corrupt or unjust collector. ${ }^{44}$ The classical Shici position, for example as given by Țūsī in his Hiläf, is that an unjust or sinning Imam is a contradiction in terms because the Imam is incapable of error ( $m a$ s șum), and that payment of zakät could only be legitimate if it reached its legitimate recipients. ${ }^{45}$ However, this position represents a classical, crystallised and systematised Shici law, rather than the position of the Imami Shici Imams, whose statements on this topic give a more ambivalent, shifting picture than Țūsī would have us believe. ${ }^{46}$ In fact, the Imamic hadiths show evidence of having been formed in dialogue

40 For the piety-minded opposition to Umayyad rule, see HoDGSON 1974, I: 241-279. See also the historical framework provided by SCHACHT 1964.

41 Steven Judd has provided a salutary critique of the oversimplified image that, 'the 'Abbaasids were religious; the Umayyads were not', and that Hodgson's idea of the 'piety-minded opposition' to the Umayyads implied that the scholarship of the hadith scholars and legal scholars under the Marwanids was 'inherently subversive, if not openly revolutionary'. JUDD 2014: 5.

42 For possible evidence of such governmental innovation, see SIJPESTEIJN 2013: 195.

43 The different positions on this question are summarised by ZYSOW, 'Zakāt', $E I^{2}$.

44 See Māwardī, quoted by CALDER 1981: 474, and below.

45 According to Țūsī, both al-Šăfic̄ (fisq) of a Caliph did not invalidate their Imamate, while many of the jurists, including some of the companions of al-Šăf̌č believed that sinning would invalidate an Imamate, presumably thereby making the payment of zakāt to him impossible. Al-ṬŪsī, Hilāf, II: 32-33.

46 And more complicated than what is suggested by Kohlberg's comment, based on his reading of Kulaynī's Kāfī and Ṭūsī's Niyāha, that 'Both zakāt al-māl [...] and zakāt al-fițra [...] may only be distributed 
with the broader spectrum of juristic opinions amongst the pious opposition. As we shall see, the hadiths of Imams Bāqir and Șādiq are also contradictory in significant ways.

The statements of the Shici Imams are, in fact, comparable in several ways to the discourse in early Sunni texts. Key questions include whom should one pay zakāt to; whether zakât counts if it is extracted by a ruler coercively; whether and under what circumstances the individual should distribute taxes autonomously; and which kinds of people constitute legitimate or preferable recipients for zakāt. While the Shia may have objected to Umayyad power, in some statements, the Shi'i Imams clearly state that the canonical taxes taken by the rulers are legitimately counted towards a Muslim's ritual duty. Several Imamic hadiths make the point that zakāt and other taxes taken through coercion by the authorities are to be counted as fulfilling one's obligation to pay the canonical taxes. These tend to deal with the 'visible' property that can be ill concealed from tax collectors: livestock, the produce of agriculture and mines. ${ }^{47}$ In one such report, Șādiq is depicted as saying that, given the option, it is preferable not to pay zakāt to the Umayyad-era caliphal authorities:

Abū 'Abd Allāh [Ṣādiq] (AS) said regarding zakāt: 'Whatever Banū Umayya takes from you, that is counted [towards your zakât], but do not give them anything if you are able, for [one's] property will not last in this case if you pay zakāt twice (? - fa-

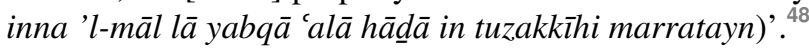

Ultimately, despite the preferred principle of avoidance of the caliphal taxman, believers are given a pragmatic dispensation from having to pay zakāt twice in the case of coercive collection of taxes, apparently in order to avoid the unnecessary diminution of capital. It is interesting to note the specifically Umayyad context, which locates this statement in a particular political landscape of the pious opposition to the Umayyads. This Umayyad context and the tolerant attitude to governmental collection suggest that this may well be an early opinion, contrasting to later, more intransigent Imami juristic opinions.

The position ascribed to Șādiq may be compared with that of his fellow Medinan, Mālik b. Anas (d. 179/795) as reported by the Māliki Șaḥnūn (d. 240/855), who recalls a question to Mālik about the case of Hāriğites who conquer a land and usurp the șadaqāt and the harāğ. ${ }^{49}$ Mālik is quoted as responding, 'I do not see that it should be taken from them a second time'. ${ }^{50}$ Mālik's case deals with the rule of the Hāriğites instead of the Umayyads, ${ }^{51}$ but the legal question is the same: do canonical taxes collected by an illegitimate authority under coercion still count for the fulfilment of the believer's ritual duties? While Mālik and

among Imāmīs'. See KOHLBERG 1985: 101.

47 Kulaynī, al-Käfï, III: 543-544; IBn BĀBŪYAH, Faqūh, II: 42; 3:543. These deal with overlapping taxation categories, including zakāt, harāăg and 'ušr , the distinction between which was a topic of disagreement between early jurists. See SATO, 'Ushr', $E I^{2}$.

48 Kulaynī, al-Käfí, III: 543.

49 Șạnnūn continues to invoke other authorities to back up Mālik, also adding the consideration of tolls and taxes on 'bridges and roads', SAḤNŪN, al-Mudawwana al-Kubrā, I: 285.

50 Ibid.

51 The passage from Ṭūsī’s hilāf cited above similarly deals with a usurping (mutagaallib) ruler. Ṭūsī, Hilāaf, II: $32-33$. 
Șādiq may not see eye-to-eye on the identity of the Imam, they do, in this case, appear to have the same position on this question.

Thus, we may say that, in conformity with an early Sunni Medinan juristic opinion on the subject, some Imamic statements indicate that payment of zakāt to illegitimate ruling Imams is to be tolerated, if not celebrated. This is in contrast with the classical position expressed by Ṭus̄i in which the canonical taxes paid to an illegitimate Imam are, by definition, illegitimate themselves. ${ }^{52}$ However, within the corpus of Imamic statements on zakāt, we do also have statements that are intolerant to the payment of zakāt to an unjust Imam. The most extreme statement regarding the payment of zakāt not only denies that any zakāt paid to an unjust Imam could be legitimate, but furthermore, it demands that all back taxes should be repaid:

From Zurāra and Bukayr and al-Faḍīl and Muhammad b. Muslim and Burayd al'Iğlī from Abū Ğa'far [al-Bāqir] and Abū 'Abd Allāh [al-Șādiq] they spoke regarding a man who belongs to one of those heresies $\left(a h w \bar{a}^{\prime}\right)$; the Harūriyya [i.e. Hāriğites], the Murği'a or the 'Utmāniyya or the Qadariyya, then repents and knows this affair [the Imamate], and amends his opinion: should he repeat every prayer he prayed or fast or zakāt or hăğğ? Is it not incumbent upon him to repeat some of that? [The Imam] said, 'He need not repeat any of that except the zakät, which he must pay, because he gave the zakât to someone other than its proper recipients, for its proper recipients are only the ahl al-walàya [i.e. the Shia]'. ${ }^{53}$

This decision is based on a piece of juristic reasoning based on the fact that prayer, hajj and fasting do not have a recipient, and therefore pertain only to the performer, but zakāt has recipients in the world, and therefore is invalidated if it is paid to the wrong person, and assuming here that the Imam and his functionaries are the only ones with the requisite justice to make sure the zakāt reaches its correct recipients. When invalidated, the purificatory function of payment remains unfulfilled. While this is intellectually consistent, its consequences for social group dynamics are liable to be extreme, as it sets an exceptionally a high bar for conversion of one's allegiance to the Imam, ${ }^{54}$ and suggests the ritual impurity of those whose allegiance is to another Imam. Even so, in itself, repaying zakāt that has been misappropriated is not unknown in Sunni jurisprudence. As Calder notes, in the case of a corrupt tax-collector ( $\left.{ }^{\mathrm{a}} \mathrm{a} m i \mathrm{l}\right)$ :

Māwardi acknowledged that if the ultimate distribution was unjust (not in accord with the law) the individual should not in fact pay his zakāt to the 'ämil but should hide it, or, if it was taken willy nilly, should repeat the zakāt in order to gain reward. $^{55}$

The big difference between Māwardī's position and the Imams' is that the Imams explicitly invoke sectarian theological criteria rather than injustice or corruption. This position may

52 Ibid.

53 KULAYNī, al-Käfì, III: 545.

54 Dakake suggests that this would have been an unrealistic expectation. DAKAKE 2007: 248.

55 CALDER 1981: 474.

jais • 17 (2017): 280-298 
allow for attenuation according to circumstance, ${ }^{56}$ but nevertheless we may note that Bāqir and particularly Sādiq appear to move the Shi i i discourse on canonical taxes towards what will become a formal division between confessional groups, establishing matters of belief as determinants of ritual practice, and therefore also powerful determinants of social boundaries. The ritual implications extend beyond zakāt itself, for it was understood that unless zakāt was paid in its proper place, prayer would be invalidated. ${ }^{57}$ From the perspective of dating it is interesting to note that the rather specific 'heretical' groups mentioned here are early sects, though they continue to survive in the heresiographical imagination, ${ }^{58}$ and therefore might easily be a later construction of groups known to have been active in the Umayyad period.

We are faced with a problem when we compare this latter report of Bāqir and Șādiq, which is intolerant to mispaid zakät, with the previous Imamic report, which is more tolerant of, albeit not encouraging towards, payment to the Umayyads. What is the explanation for this clear divergence? It is possible that it was generated later, as we might be led to suspect from the fact that the more intolerant attitude conforms more closely to the more hermetic sectarian divisions of the classical Shici jurists? One possibility, then, is that the apparently more tolerant opinion is earlier, before the crystallisation of sectarian positions. Another explanation may relate to the precise context implied. In the latter report from Bāqir and Șādiq the context is subtly different, as it does not refer to faithful Shia who pay $z a k \bar{a} t$ due to coercion (a context also applicable to the opinion ascribed to Mālik) but rather it refers to committed members of 'heretical' non-Shici groups who later convert to follow the right Imam. Thus, the reason for the discrepancy may be due to an implicit distinction between payment to an unjust Imam by faithful Imamis for reasons of coercion, and payment to an unjust Imam by those who are fully committed to that unjust Imam. In the latter case, one's zakāt has not been legitimately paid, because one was living beyond the community of salvation, and therefore must be paid again. ${ }^{59}$

56 This hadith is followed by one in which Șādiq states that if a man does his best to identify the appropriate recipient, but he cannot, then he need not pay his zakāt a second time, KULAYNī, Käfì, III: 545.

57 Ibid.: 499; 506. The danger of non-payment of zakāt was no insignificant matter. Because of failure to properly perform zakāt, we are told, the majority of Muslims were destined for damnation. Ibid.: 497.

58 Harūriyya is one of the names applied to the early Hुāriğites, whose successive uprisings posed a prominent threat to governmental authority in Iraq up until the end of the Umayyad period. See DELLA VIDA, 'Khāridjites', $E I^{2}$. The word murği ${ }^{\prime} a$ did continue to be used by Shia both as a specific theological label and as a more general derogatory name for Sunnis into the 'Abbasid period. See MADELUNG, 'Murdji'a', $E I^{2}$. The 'Uthmāniyya did not continue to exist beyond the 4th/10th century, Crone, "Uthmāniyya', $E I^{2}$. The Qadariyya, were an equally early movement, the precursors of the Mu'tazila in upholding human free-will, vAN ESS, 'Kadariyya', $E I^{2}$.

59 This explanation is plausible, but it does not match the explicit reason given by the Imam: the zakāt has not reached its proper recipient, a reason which would presumably hold the same regardless of conviction or coercion. 


\section{Generational tension between Imamic opinions}

One possible explanation for the internal contradictions between the Imamic statements is that there was a generational change in policy between the Imams as they responded to the great upheavals of their day: the uprisings and instability of the late Umayyad times followed by the regime change and suppression of the Shia under the 'Abbasids. The existence of a generational change in Imamic opinion is, in fact, explicitly borne out within some of their hadiths. Șādiq appears in one statement as explicitly raising questions about his father's legal opinions, in the process of developing his own position on the subject:

Sulaymān b. Hāāid said:

I heard Abū 'Abd Allāh [al-Ṣādiq] say, 'My father [Bāqir]'s companions came to him and asked him about [the taxes which] the Sultan takes, so he felt compassion for them (fa-raqqa lahum), though of course he knew that zakāt is not licit except for its proper recipients, and he ordered them to count it [as part of what they need to pay for zakāt] and by God! I continued to cogitate about them, and I said to him, "Oh father! If they listen to you, then not one of them will pay zakāt!" And he said, "Oh my son! [That is] a duty/tax (haqq) that God prefers to make manifest (haqqun ahabba 'llāhu an yuẓhirahu)", 60

This is a difficult passage, but it is clear that Bāqir is allowing his followers to count what the Sultan appropriates towards their canonical zakāt, even though the illegitimacy of the Caliph means that the zakāt might not go to its proper recipient. In this hadith there appears to be a tension between Șādiq's idealism and Bāqir's pragmatic dispensation to allow payment to the illegitimate Caliph to fulfil ritual requirements, regardless of its ultimate destination. In this sense Bāqir appears to fit into the framework of pragmatic tolerance that existed among Sunni jurists, while Șādiq seems to take a step closer towards the classical Imami opinion, which regards only payments to the true Imam, that is, the Shici Imam, as legitimate. Can we read this as a generational shift? If so, it is not the only such hadith that suggests a generational shift. ${ }^{61}$ While this does not clear up the problem of contradiction entirely (after all, the most intransigent statement requiring the payment of back taxes is ascribed to both Bāqir and Șādiq) it seems plausible that the contradictory nature of the Imamic law of zakāt may, in part, have been due to generational development in the policy between Bāqir and Șādiq, as they responded to changing circumstances. Tolerance towards caliphal collection seems to have been the Imamic norm, stemming from a pragmatism common also to some Sunnis, however, as later statements ascribed to Șādiq's son, Mūsā al-Kāzim, also grant dispensations for his followers to pay zakāt to the caliphal agents under circumstances of coercion. ${ }^{62}$ It seems likely then, that, in contrast to the general Imami Shici doctrinal assertion of the universality, ahistoricity, and harmoniousness of the

60 KULAYNI, al-Kāfit, IIII: 543.

61 See, for example, Sādiq's gloss on the Quranic ganīma verse (8:41), in which he appears to contrast his opinion with his father's. KULAYNI, al-Käfi, I: 544. It would be interesting to take a larger sample of hadiths on related topics to see if there are apparent generational differences between Bāqir and Șādiq that might indicate similar patterns.

62 KULAYNī, al-Kāfi, III: 543-554; IBN BĀBŪYAH, Faqīh, II: 42. 
law of the Imams, instead, they responded to political circumstances to make judgements about the payment of taxes. This generated internal contradictions that were later glossed over by the Occultation era classical Twelver jurists.

\section{Giving to the initiated}

If an individual distributes the zakāt autonomously instead of giving it to the Imam for distribution this raises a further set of issues, in particular in determining an appropriate recipient. Though the classes of people eligible to receive zakât were understood to have been explicitly designated in Quran 9:60, the religious affiliation of the recipients also came to be a consideration affecting the proper distribution of the zakatt. The Imamic hadiths imply the existence of inner and outer circles of religious legitimacy that were understood as separate categories. The hallowed inner circle consisted of the ahl al-walaya, Shic $i$ Muslims who recognised the rightful Imam. The next circle consisted of unknown Muslims, followed by non-Muslims, and in the outer darkness, to be avoided at all costs, were the vocal anti-Shi' $i$ Muslims (the nāșibiss), to whom zakāt was categorically denied. ${ }^{63}$

In the following report on the distribution of zakāt we are given a further sense of Ğa'far al-Ṣādiq's shifting policy in defining who is a legitimate recipient of zakāt. In this report, the operative element is not the recipient's professed religious identity, but what the recipient 'knows', which may, perhaps, allude to sectarian affiliation, to one's spiritual ranking, or to some other criterion. Ğa'far al-Șādiq is questioned by Zurāra about whether the Quranically-stipulated recipients should receive the zakāt, 'even if they do not know?' Șādiq responds as follows:

The Imam gives to all of those because they concede obedience to him. And Zurāra said: 'And if they do not know!?' And [Șādiq] replied: 'Oh Zurāra, if those who know were given [the sadaqa], to the exclusion of those who do not know, then not enough proper recipients would be found for the alms. And we only give to the one who does not know in order to encourage him in faith, and make him firm in it. But as of today, you and your companions must not give to anyone but someone who knows. Whoever you find among those Muslims who is knowing, then give to him rather than the [ordinary] people $(n \bar{a} s){ }^{, 64}$

This report is mysteriously elliptical. We cannot be exactly sure what it is that these people do not know. It might be the identity of the true Imam, thereby equating this report with the above-mentioned report, which refers to the people of walaya. In this case, 'those who do not know' might perhaps refer to Zaydi-style Shia who do not acknowledge the distinctive claim of the Fatimid lineage. Or it might refer to some kind of esoteric or initiatory knowledge that neophytes are excluded from, as in the Fatimid Ismaili, ${ }^{65}$ Nușayri, ${ }^{66}$ or

63 See, for example, the test-case of the unknown beggar, KULAYNī, al-Kāfì, IV: 13. See also KOHLBERG 1985. Dakake has a similar model for envisaging the Shici community as an inner circle within the wider Muslim community. DAKAKE 2007: 241.

64 IBN BĀBŪYAH, Faqīh, II: 4-7.

65 See DAFTARY 1998: 92-93. 
Druze models. ${ }^{67}$ We see, however, that there are not enough of these initiates to act as recipients for the șadaqa of all the Shia. Șādiq indicates that Zurāra and his companions ${ }^{68}$ are in a select circle advised to act in a particularly meticulous manner by distributing sadaqa only within the circle of initiates. This would also appear to adjust our understanding of what Dakake sees as an essentially non-hierarchical community in which charity is regulated according to membership in the Shic $i$ community in its largest possible sense. ${ }^{69}$ This kind of inward-looking fiscal practice, if carried through, would lead to a community with an internalising, insular sacred economy centred upon the figure of the Imam, and perhaps was the basis for the core of the intensely sectarian community that emerged over the course of the 'Abbasid era.

\section{Conclusion}

In conclusion, the creation of a sectarian community is not just a matter of belief, but also the introduction of structures and protocols that crystallise and formalise boundaries. While we cannot pinpoint exactly the moment of genesis of the Imam-centred zakāt collection procedures in the Imami community, these statements of Bāqir and Șādiq clearly express a set of protocols that tend to separate their followers from the wider community, establishing a hierarchy of excellence and access to the Imam. Given the scanty sources, Imams' hadiths are among our best evidence for the origins of the insular Imami fiscal system: a system which became so very important at the time of the death of Kāzim, and even more so upon the death of al-'Askarī, when it was the fiscal agents who announced the new era of the Occultation, and took quasi-Imamic authority upon themselves. There are three aspects which give us hope that what we are looking at reflects some historical reality: firstly, the Imamic hadiths diverge from classical Imami positions expressed in works of hadith and fiqh from the fourth/tenth century, and especially the fifth/eleventh century, being less intransigent, and closer to Sunni discourses, suggesting that they may well represent an earlier state of thinking and acting, in which Shici discourse was less clearly demarcated from proto-Sunni and other schools of thought. Secondly, there are indications within the hadith reports themselves that the Imams recognised change between their opinions, suggesting that they were reacting to historical circumstances and the developing legal discourse. While we cannot clearly correlate these changes with particular historical events, it is significant that they appear to be engaged with the evolution of doctrine. They do not claim to express timeless truths, but suggest shifting realities that must be explained and justified. Thirdly, some of these hadith reports allude to the specific historical context of the Umayyad period, suggesting perhaps that the Imamic position on zakāt began to be

66 See, for example, FRIEDMAN 2010: 115-118.

67 See Hodgson, 'Durūz', $E I^{2}$.

68 Zurāra b. Acyan died in 150/767, placing him firmly during the lifetimes of Bāqir and Șādiq. For the biography of Zurāra, based on Nağāšĩ and Kaššī, see SACHEDINA 1988: 42.

69 This stems from Dakake's reading of the phrase ahl al-waläya, with relation to the giving of charity. See DAKAKE 2007: 247-249.

jحis • 17 (2017): 280-298 
articulated against the backdrop of political instability and opportunity towards the time of the fall of the Umayyad dynasty. If the development of the Imamic legal discourse on sadaqa is compared to that on hums and other revenue categories, and institutional mechanisms in the Imami community, we will be able to understand these processes more broadly, including the question of authenticity, and the generational developments.

The statements of the Imams during the second/eighth century begin to reflect, though not uniformly, a movement towards the creation of a distinct sectarian community; a community whose members are recommended to avoid paying the canonical Islamic taxes to the caliphal government, though not to the extent of active civil disobedience. Even when distributing the alms autonomously, the individual is not freed from considerations of communitarian affiliation. The autonomous payment of zakāt has two aspects that indicate the developing communitarian logic of an insular Imami sacred economy: ${ }^{70}$ firstly, giving within the circle of Imamis is preferable to giving to non-Shia, non-Muslims, and especially to anti-Shi'i Muslims. Secondly, even in payments to other Shia, there appears to be a categorical distinction between the initiated, 'those who know', and the uninitiated, 'those who do not know'. The context implied in the report suggests that a different set of rules apply to the inner clique of the Imams' supporters: Zurāra and his companions. This, then, perhaps suggests the context in which the creation of an insular sectarian fiscal regime was erected, not by Imamic decree to the entirety of the Shia ${ }^{71}$ but by the gradual development of special protocols for those closest to the Imam. This group of like-minded men was motivated by the broader scripturalist turn that also characterised the development of early Sunnism, ${ }^{72}$ but they set themselves apart by their pious attachment to the Imam, leading them to bind themselves by rules of greater strictness than their co-religionists in the broader society. This begs the question: did there continue to be an inner clique of initiates set apart from the wider group of followers of the Imams, ${ }^{73}$ or did the ritual practices of those paradigmatic Shici notables ultimately trickle down and extend to a greater Shici community, including particularly strictly regulated habits with regard to the payment of canonical Islamic taxes?

70 See above, footnote 11.

71 This, in any case, was very likely not a categorisation that had much meaning at this time of fluidity and rapidly changing group identities. On the lack of homogeneity of early Shicism, see VAN ESS 1991, I: 272274.

72 By 'scripturalist turn' I refer to the general tendency in the second/eighth and third/ninth centuries to preserve, produce and transmit explicit, and increasingly written, texts in order to support existing practices and ideas, a tendency that gave rise to the great hadith collections, Quranic exegesis, and hadithbased fiqh works.

73 This possibility is interesting to consider with regard to Amir-Moezzi's largely theological-doctrinal conception of early Shic ism as focused upon an esoteric core. See AMIR-MOEZZI 1994. 


\section{Bibliography}

\section{Sources}

al-Nu'MĀN, al-Qāḍī Abū Ḥanīfa an-Nu'mān b. Muḥammad at-Tamīmī. Dacẳim al-Islām / ed. A.A. Fyzee. al-Qāhira: Dār al-ma'ārif, 1370 AH [1951].

IBN BĀBŪYAH, 'Alī ibn 'Ubayd Allāh. Kamāl al-dīn wa-tamām al-ni'mah fĭ ịtbāt al-ġayba / ed. 'Alī Akbar Ġaffārī. Tehrān: Intišārāt-i masğid-i muqaddas-i ğumrukān, 1384 AH [2006].

- Man lā yaḥduruhu 'l-faqīh / ed. 'Alī Akbar Ġaffārī. Qumm: Ğamācat al-mudarrisīn fî 'l-ḥawza al'ilmiyya fī Qumm al-muqaddasa, 1392 AH [1972-3].

al-HāDī ilà 'l-Ḥaqq Yahyā b. al-Ḥusayn. Kitāb al-ạ̣kām fì 'l-ḥalāl wa'l-ḥarām / ed. al-Murtạ̣ā b. Zayd al-Maḥțūrī al-Ḥasanī. Șan'ầ': Maktabat Badr, 2014.

al-Ṭūsī, Muḥammad b. al-Ḥasan. Kitāb al-Hilāaf fī 'l-fiqh / ed. 'Alī al-Hูurāsānī. Qumm: Mu’assasat al-našr al-islāmī, 1404 AH [1984].

SAḤNūN, 'Abd al-Salām ibn Sa'̄ìd. al-Mudawwana al-Kubrā. al-Qāhira: Maṭacat al-sa ādah, 1906?

al-Kulayñ̄, Abū Ğacfar Muhammad b. Ya'qūb. Al-Kāfĭ. Tehrān: Dār al-kutub al-islāmiyya. 13881391 AH [1968-1971].

\section{Secondary Literature}

AmiR-MoezZI, Mohammad Ali. 1994. The Divine Guide in Early Shi ism / translated by David Streight. New York: SUNY Press.

ANSARI, Hassan. 2013. "The Kitāb al-Wașiyya of 'Īsā b. al-Mustafād: The History of a Text". In: COOK, HAIDER, RABB \& SAYEED (eds.) 2013: 67-79.

ArJomand, Said Amir (ed.). 1988. Authority and Political Culture in Ši ism. Albany, NY: SUNY Press.

Asatryan, Mushegh. 2014. "Bankers and Politics: The Network of Ši i i Moneychangers in EighthNinth Century Kufa and their Role in the Shi i Community". Journal of Persianate Studies, 7: 121.

Bashear, Suliman. 1993. "On the Origins and Development of the Meaning of Zakāt in Early Islam". Arabica, 40.1: 84-113.

Brown, Jonathan. 2009. Hadith: Muhammad's Legacy in the Medieval and Modern World. Oxford: Oneworld, 2009.

Bulliet, Richard. 1979. Conversion to Islam in the Medieval Period: An Essay in Quantitative History. Cambridge, MA: Harvard University Press.

BuyukKara, M. Ali. 2000. "The Schism in the Party of Mūsā al-Kāzim and the Emergence of the Wāqifa”. Arabica, 47.1: 78-99.

CALDER, Norman. 1981. "Zakāt in Imāmī Shīī Jurisprudence, from the Tenth to the Sixteenth Century A.D.". Bulletin of the School of Oriental and African, 44.3: 468-480.

- . 1982. "Khums in Imāmī Shīî Jurisprudence, from the Tenth to the Sixteenth Century A.D.". Bulletin of the School of Oriental and African Studies, 45.1: 39-47.

COOK, Michael / HAIDER, Najam / RABB, Intisar / SAYEED, Asma (eds.). 2013. Law and Tradition in Classical Islamic Thought. New York: Palgrave Macmillan.

CRONE, Patricia. “Uthmāniyya”. In: Encyclopaedia of Islam, $2^{\text {nd }}$ edn.

CRONE, Patricia / Hinds, Martin. 1986. God's Caliph: Religious Authority in the First Centuries of Islam. Cambridge: Cambridge University Press.

jحis • 17 (2017): 280-298 
DAFTARY, Farhad. 1998. A Short History of the Ismailis. Edinburgh: Edinburgh University Press.

DAKAKE, Maria Massi. 2007. The Charismatic Community: Ši ite Identity in Early Islam. Albany, NY: SUNY Press.

DELLA VIDA, Giorgio. "Khㅡāididjites". In: Encyclopaedia of Islam, $2^{\text {nd }}$ edn.

FRIEDMAN, Yaron. 2010. The Nușayrī-'Alawīs: An Introduction to the Religion, History and Identity of the Leading Minority in Syria. Leiden: Brill.

Gleave, Robert. 2001. "Between Hadīth and Fiqh: The 'Canonical' Imāmī Collections of Akhbār". Islamic Law and Society, 8.3: 350-382.

— . 2010. "Early Development of the Shīî Law of Mut'a". Paper given at "The Study of Shi'i Islam: The State of the Field'. Issues of Methodology and Recent Developments, a Colloquium. Institute of Ismaili Studies, London, 20-22 September 2010.

- . "Khums". In: Encyclopaedia of Islam, $2^{\text {nd }}$ edn.

Goldziner, Ignaz / van ARENDOnK, Cornelis / TRitTon, Arthur Stanley. "Ahl al-bayt”. In: Encyclopaedia of Islam, $2^{\text {nd }}$ edn.

HAIDER, Najam. 2003. The Birth of Sectarian Identity in 2nd/8th century Küfa: Zaydism and the Politics of Perpetual Revolution. PhD Dissertation. Princeton University.

— . 2009. "Prayer, Mosque, and Pilgrimage: Mapping Shīî Sectarian Identity in 2nd/8th Century Kūfa". Islamic Law and Society, 16.2: 151-174.

- .2011. The Origins of the Shī'a: Identity, Ritual, and Sacred Space in Eighth-Century Küfa. New York: Cambridge University Press.

HAYES, Edmund. 2015. The Envoys of the Hidden Imam: Religious Institutions and the Politics of the Twelver Occultation Doctrine. $\mathrm{PhD}$ dissertation. University of Chicago.

HENNIGAN, Peter. 2014. The Birth of a Legal Institution. Leiden: Brill.

Hodgson, Marshall G.S. 1955. "How Did the Early Shî'a become Sectarian?" Journal of the American Oriental Society, 75.1: 1-13

- . 1974. The Venture of Islam. Vol. 1: The Classical Age of Islam. Chicago, IL: Chicago University Press.

— . "Ḍja far al-Ṣādiḳ”. In: Encyclopaedia of Islam, $2^{\text {nd }}$ edn.

—. "Durūz". In: Encyclopaedia of Islam, $2^{\text {nd }}$ edn.

Hugh-Jones, Stephen / Laidlaw, James (eds.). 2000. The Essential Edmund Leach. Vol. 1: Anthropology and Society. New Haven, CT: Yale University Press.

JudD, Steven. 2014. Religious Scholars and the Umayyads: Piety-minded Supporters of the Marwānid Caliphate. Abingdon: Routledge.

Kohlberg, Etan. 1985. "Non-Imāmī Muslims in Imāmī fiqh". Jerusalem Studies in Arabic and Islam, 6: 99-105.

— . 1988. "Imam and Community in the pre-Ghayba Period". In: ARJOMAND (ed.) 1988: 25-53.

— . 1991. Belief and Law in Imāmī Shīicism. Aldershot: Variorum, 1991.

— . "Muhammad b. 'Alī Zayn al-'Ābidīn, Abū Dja fáfar, called al-Bāḳir”. In: Encyclopaedia of Islam, $2^{\text {nd }}$ edn.

— . "Mūsā al-Kāzịm". In: Encyclopaedia of Islam, $2^{\text {nd }}$ edn.

LEACH, Edmund. 2000. "Ritual”. In: Hugh-Jones / LAIDLAW (eds.) 2000: 165-174.

MADELUNG, Wilferd. "Hishām b. al-Ḥakam”. In: Encyclopaedia of Islam, $2^{\text {nd }}$ edn.

- . "Murdjiia". In: Encyclopaedia of Islam, $2^{\text {nd }}$ edn.

ModArRessi, Hossein. 1983. Kharāj in Islamic Law. Tiptree: Anchor Press. 


\section{Edmund Hayes}

—. 1993. Crisis and Consolidation in the Formative Period of Shi'ite Islam. Princeton: Darwin Press.

- 2003. Tradition and Survival: A Bibliographical Survey of Early Shīite Literature. Oxford: Oneworld.

Newman, Andrew. 2000. The Formative Period of Twelver Shi ism. Richmond: Curzon.

Noth, Albrecht / ConRAD, Lawrence. 1994. The Early Arabic Historical Tradition: a Source-Critical Study. Translated by Michael Bonner. Princeton: Darwin Press.

SATO, T. “Ushr”. In: Encyclopaedia of Islam, $2^{\text {nd }}$ edn.

SACHEDINA, Abdulaziz. 1988. The Just Ruler (al-sultān al-āadil) in Shīite Islam: the Comprehensive Authority of the Jurist in Imamite Jurisprudence. Oxford: Oxford University Press.

SCHACHT, Joseph. 1964. An Introduction to Islamic Law. Oxford: Clarendon Press.

SiJPESTEIJN, Petra. 2013. Shaping a Muslim State: The World of a Mid-Eighth-Century Egyptian Official. Oxford: Oxford University Press.

VAn Ess, Josef. 1991. Theologie und Gesellschaft im 2. und 3. Jahrhundert Hidschra. Berlin: De Gruyter.

—. "Kadariyya". In: Encyclopaedia of Islam, $2^{\text {nd }}$ edn.

Zysow, Aron. "Zakāt". In: Encyclopaedia of Islam, $2^{\text {nd }}$ edn.

(C) Edmund Hayes, Leiden University

4 e.p.hayes@hum.leidenuniv.nl 